\title{
On Improving the Development Level of Agricultural Cooperation between China and Africa: The Case of Zimbabwe
}

\author{
Jiaxiu Wang \\ School of Marxism, Zhejiang Normal University, Jinhua, China \\ Email: wangjiaxiu@zjnu.edu.cn
}

How to cite this paper: Wang, J. X. (2021). On Improving the Development Level of Agricultural Cooperation between China and Africa: The Case of Zimbabwe. Open Journal of Political Science, 11, 561-568. https://doi.org/10.4236/ojps.2021.114036

Received: January 4, 2021

Accepted: August 21, 2021

Published: August 24, 2021

Copyright $\odot 2021$ by author(s) and Scientific Research Publishing Inc. This work is licensed under the Creative Commons Attribution International License (CC BY 4.0).

http://creativecommons.org/licenses/by/4.0/

\section{(c) (i) Open Access}

\begin{abstract}
Land is the most important resource in Africa and it has a wide range of economic, political, social and religious significance. The agricultural cooperation between China and African countries under the China-Africa Community with a Shared Future has made great achievements. The agricultural economy is one of the main sources of income for Zimbabwe's national wealth. China-Zimbabwe agricultural cooperation has promoted the rapid recovery and development of Zimbabwe's national economy. However, there are still many outstanding problems in specific cooperation practices, such as the one-way tilt of aid, low added value of crops, and serious debt problems. These questions influence the advancement of agricultural cooperation between the two countries in varying degrees. Based on literature analysis, this article starts from the status quo of agricultural cooperation between China and Zimbabwe, deeply analyzes the problems existing in the development of agricultural cooperation between China and Zimbabwe, and proposes targeted countermeasures to promote the agricultural cooperation between China and Zimbabwe to a higher level. In turn, the further development of China-Africa agricultural cooperation will promote the better realization of the development of a China-Africa Community with a Shared Future.
\end{abstract}

\section{Keywords}

Relations between China and African Countries, Agricultural Cooperation, Development of China and Zimbabwe

\section{Introduction}

The year 2021 is the $65^{\text {th }}$ anniversary of the opening of diplomatic relations be- 
tween China and African countries. Over the past 65 years, China and African countries have enhanced mutual understanding and mutual learning between civilizations, ushering in a new era of China-Africa relations. China's agricultural cooperation with Africa began in the 1950s. In 1959, China's provision of food aid to the government of Guinea marked the beginning of China-Africa agricultural cooperation. The year 2021 marks the $41^{\text {st }}$ anniversary of the establishment of diplomatic relations between China and Zimbabwe. The cooperation between China and Zimbabwe is an important part of cooperation between China and Africa. Zimbabwe is known as the "Granary of Southern Africa" and is located between the Zambezi and Limpopo rivers (Guo, 2020). It is a multi-ethnic and diverse state. Dating back to the pre-colonial period, the vast majority of people in Zimbabwe were farmers and cultivators (Ian \& Brian, 2000). These farmers have a strong attachment to the land, not only because it has economic significance as a natural resource to produce food, but also because it has the spiritual significance of family maintenance as a heritage of ancestors (Mothibe, 1996; Terence, 1986). The agricultural economy is one of the main sources of income for Zimbabwe's national wealth, contributing $14 \%$ to $18 \%$ of its gross domestic product, as well as about $40 \%$ of export income and about $60 \%$ of industrial raw materials. The country's agricultural population accounts for $75 \%$ of the country's population, and the agricultural sector absorbs $26 \%$ of the country's employed population, reaching 320,000. Since the establishment of the China-Africa Cooperation Forum, agriculture has been an important content of cooperation. During the first China-Africa Cooperation Forum, both China and Africa "recognized the importance of developing agriculture to alleviate poverty and ensure food security" (Jiang, 2014). In the "China-Africa Economic and Social Development Cooperation Program" adopted, it was clearly stated that agriculture is one of the main areas of China-Africa cooperation. With the continuous improvement of the relevant mechanisms of the Forum on China-Africa Cooperation, China-Africa agricultural cooperation has moved from the initial consensus stage to the multi-level comprehensive cooperation stage. However, many problems have also been exposed when China-Africa agricultural cooperation has shown new features. China-Africa agricultural cooperation is also facing many new challenges. The African continent is still the region with the most food insecure population in the world. Solving the problem of food security in Africa is an important goal of China-Africa agricultural cooperation. With the continuous deepening and maturity of China-Africa cooperation from policy to mechanism, the prospect of China-Africa agricultural cooperation is quite bright.

\section{The Development Status of China-Zimbabwe Agricultural Cooperation}

China has always pursued a foreign policy with non-interference in the internal affairs of sovereign countries at its core, and it is a natural and friendly cooperative partnership with Zimbabwe (Wikipedia, 2012). In 2009, the Chinese gov- 
ernment sent to Zimbabwe a 10-person senior agricultural expert group covering agronomy, farmland irrigation, wheat and corn production and research, rice planting, aquaculture, animal husbandry, animal disease prevention and control, and dry farming. Chinese experts rushed to the field to understand the problems in Zimbabwe's agricultural production on the spot, and combined the successful experience of China's agricultural development and agricultural technology with the local actual conditions to scientifically and dialectically guide the local agricultural production.

Many Chinese companies have established their own companies in Zimbabwe to seek business partnerships with local farmers. Chinese companies have established contract agriculture with tobacco and cotton growers in Zimbabwe. For example, China's Tianze Tobacco Company accounted for $11.7 \%$ of the contracted crops sold in the market in 2011. China-Zimbabwe contract agriculture and the influx of a large number of buyers into the Chinese market have made important contributions to the revival of the tobacco industry in Zimbabwe. Over the years, China has become Zimbabwe's largest purchaser of tobacco. Between 2010 and 2011, China-Zimbabwe's tobacco exports more than doubled, constituting 21\% of Zimbabwe's 2011 export crops, and raising the national average price of the crop, which effectively stimulates Zimbabwe's economic recovery. China has become the second largest trading partner and the largest buyer of Zimbabwean tobacco. Zimbabwe mainly exports tobacco, ferrochrome and other mineral products to China, while China exports light industrial products, electromechanical and high-tech products to it. In 2018, the bilateral trade volume between China and Zimbabwe was US\$1.335 billion, a year-on-year increase of $1.42 \%$ (MIC, 2012).

In agricultural export income, cotton ranks second, second only to tobacco. Cotton is regarded as Zimbabwe's "platinum" and is one of the main economic crops in Zimbabwe. It is also one of the main sources of foreign exchange income. During 2009, lint exports achieved a revenue of 150 million dollars. It is estimated that there are 300,000 small farmers, each with an average planting area of 1 hectare, accounting for more than 99\% of the crops, 95\% of which are planted through contract arrangements. According to the contract arrangement, the China-Zimbabwe cooperative company provided farmers with seeds, fertilizers and chemicals, and the farmers were obliged to hand over part of the harvested crops. On May 21, 2019, the Ministry of Agriculture and Rural Affairs of China donated USD 136,000 worth of agricultural equipment and materials to the Zimbabwe Ministry of Agriculture in Harare, the capital of Zimbabwe. This batch of equipment and materials will be used by the Ministry of Agriculture of Tianjin and the China-Aided Agriculture Expert Group for the joint use of agricultural research, production, and agricultural technology training. These measures will help improve Zimbabwe's agricultural production and research capabilities. Zimbabwe has four major cotton-producing areas in the country, with various cotton-related industries: ginning, oil pressing, textiles and clothing. In 
2009, the China-Africa Development Fund, Qingdao Ruichang Cotton Industry Co., Ltd. and Qingdao Huifu Textile Co., Ltd. jointly funded the establishment of China-Africa Cotton Industry Development Co., Ltd., which entered Zimbabwe in 2013, with a cumulative investment of approximately US $\$ 30$ million, making it the second largest cotton company in Zimbabwe. On June 27, 2019, during the first China-Africa Economic and Trade Expo, China Railway International Group and the Ministry of Agriculture of Zimbabwe signed a memorandum of cooperation for the China-Zimbabwe-Guibi Modern Agricultural Industrial Park project, aiming to build a China-Zimbabwe agricultural industry cooperation platform, including agricultural machinery and agricultural materials. A relatively complete agricultural industry chain, including supply, agricultural planting, storage, agricultural product processing, and sales, contribute to the improvement of Zimbabwe's agricultural industrialization level (Langton Mukwereza, 2013).

Currently completed between China and Zimbabwe, the ongoing or planned agricultural assistance programs include agricultural technology demonstration centers, emergency food assistance, loan agreements with the Export-Import Bank of China, agricultural machinery donated by the Sichuan Provincial Government of China, targeted at the Ministry of Agriculture of Zimbabwe, and training conducted by key government personnel. China's agricultural cooperation in Zimbabwe provides comprehensive training for agricultural personnel, students in related disciplines and farmers; provides scientific research information on agricultural research including biotechnology research, etc., and aims to build a China-Zimbabwe agricultural industry cooperation platform to form a supply of agricultural materials including agricultural machinery. A relatively complete agricultural industry chain, including agricultural planting, storage, processing and sales of agricultural products, has helped Zimbabwe improve the level of agricultural industrialization.

\section{Problems in the Development of China-Zimbabwe Agricultural Cooperation}

First, China-Zimbabwe's agricultural cooperation plan is more unilateral in nature (Yang \& Chen, 2018). In 2011, the Export-Import Bank of China provided Zimbabwe with a loan arrangement of US $\$ 334.7$ million to purchase tractors and support the mechanization plan of the agricultural sector in Zimbabwe. In 2012, China donated US $\$ 14$ million in emergency food aid materials to Zimbabwe, including 4910 tons of rice and 9723 tons of wheat. According to the country's annual food needs, the donation accounts for $40 \%$ and $3 \%$ of the annual rice and wheat, respectively. The Sichuan Provincial Government of China has donated a batch of agricultural machinery to Zimbabwe, including 10 agricultural trucks, 30 walking two-wheel tractors and 50 water pumps. On May 21, 2019, the Ministry of Agriculture and Rural Affairs of China donated US\$136,000 worth of agricultural equipment and materials to the Zimbabwe Ministry of 
Agriculture in Harare, the capital of Zimbabwe. This batch of equipment and materials will be used by the Ministry of Agriculture of Tianjin and the China-Aided Agriculture Expert Group for the joint use of agricultural research, production, and agricultural technology training.

Second, the pursuit of crop market benefits reduces the quality of crops. Zimbabwe's cotton crops are sold at high prices in the global market. This is because cotton is picked by hand, graded according to cleanliness and fiber length, and rolled into different grades to maintain high standards. Since 1994, the Zimbabwe cotton sector has liberalized the market, and the number of traders allowed to purchase crops has increased from 3 to more than 20. In the case of cotton production tending to stabilize, due to buyers' competition for cotton crops, a few profit-seeking contenders ignored some purchase and processing guidelines, resulting in a decline in cotton quality. Such development will damage the development of the cotton industry and weaken the good reputation of the crop in the international market in the long term.

Third, most of Zimbabwe's agricultural products are exported to China in the form of raw or semi-processed rather than finished products. Chinese agricultural enterprises in Zimbabwe also invest mainly in planting, picking and primary processing industries. This has reduced the income derived from exports from agricultural cooperation between the two countries and has kept Zimbabwe's overall economic activity in a downturn. Zimbabwe is one of the countries with the best climate in the world. Although Zimbabwe has an area of 390,000 square kilometers, of which arable land is about 160,000 hectares. And Zimbabwe has a population of more than 16 million, and the agricultural population accounts for $80 \%$ of the total population. The per capita land area is 3.2 hectares, and the per capita arable land area is 1.3 hectares. However, the problems of backward infrastructure, primitive production methods, insufficient input of production factors, and low technological level in these areas are more prominent. The level of agricultural mechanization is low, and agricultural production mainly depends on manpower, which affects the improvement of labor production efficiency, and it is difficult to obtain higher economic benefits.

Fourth, the debt problem in the China-Zimbabwe agricultural cooperation plan has intensified. An analysis of the UN's 2015 import growth rate data shows that Zimbabwe's population growth rate is $4.36 \%$ second in the world. In 1980, $65 \%$ of Zimbabwe's total capital was invested by foreign capital. It can be said that Zimbabwe is actually controlling its economy by foreign capital. By 2002, the net outflow of foreign capital was US\$374 million. In 2017, Zimbabwe's GDP was US $\$ 18.5$ billion, but the stock of foreign funds absorbed was US $\$ 4.628$ billion. Zimbabwe relies heavily on external funds, but external funds have little effect, which in turn causes inflation. China's cooperation plan with Zimbabwe has not changed this issue. Zimbabwe's current debt levels are unsustainable. The debt-to-GDP ratio reached 104\% in 2010 and has been deteriorating ever since. By June 2011, the country's total debt was 8.754 billion U.S. dollars. And 
foreign debt reached 6.081 billion U.S. dollars, accounting for about $70 \%$. Of the arrears, $75 \%$ are medium to long-term time horizons.

\section{Measures to Solve the Problems of China-Zimbabwe Agricultural Cooperation Development}

First of all, China has always been adhering to the humanitarian spirit to assist African countries, and China-Zimbabwe agricultural cooperation is more of a one-way trend. Thus, it is necessary to use globalization as an opportunity to open up new directions and new paths in the field of cooperation. At the same time, China and Zimbabwe have also increased the overall coordination and interaction in the field of agricultural cooperation and economic development, and provided new directions for the further development of the China-Africa Community of Shared Future, forming a two-way model in which gratuitous humanitarian assistance and market-oriented investment and trade in the agricultural sector are simultaneously initiated and advanced in both directions. Bring the content of cooperation between China and Zimbabwe in the agricultural industry into the existing framework of economic and trade cooperation between China and African countries, and Chinese enterprises are encouraged to establish deep processing and manufacturing of agricultural products in African countries. On the basis of ensuring basic humanitarian assistance to African countries, it will inject vitality into the agricultural development of Zimbabwe to promote the long-term development of the agricultural industry in African countries through market-oriented sustainable development.

At the same time, China's agricultural assistance policy for Zimbabwe still has much room for improvement. For example, attention should be paid to the simultaneous advancement of government official assistance from social organizations or enterprises. In the field of assistance, intergovernmental assistance projects and exchanges between social organizations or enterprises should be strengthened. Simultaneously cooperation between the two countries should attach importance to the influence and power of international non-governmental organizations, actively link up with relevant international organizations, and strengthen multilateral cooperation with the international community.

Second, it is essential to fully guarantee the standardization of the planting and sales of superior crops. The Cotton Growers Association and the Cotton Sales Technical Committee are composed of cotton farmers, ginners, cotton merchants, and the government. These two organizations should give full play to their role in regulating the planting and sales of cotton crops, especially promoting the standardization of capital investment links to ensure All merchants buy and roll by grade, and merchants can be used to register contracted farmers in a shared database and guarantee that they will not make "predatory" purchases, that is, they will never be allowed to deliberately lower crop prices.

Third, develop agricultural manufacturing with high added value. The contribution of manufacturing to the country's GDP fell from 20\% in 2000 to $10 \%$ in 2008. Zimbabwe's "Industrialization Policy" encourages people to benefit 
more from the country's exports and realize the employment opportunities and life improvements that this initiative may bring. But in that case, attention must be paid to the tendency of international raw material prices to rise, resulting in higher price fluctuations than manufactured products. Therefore, Zimbabwe is considering imposing taxes on raw material exports to prevent such activities. For example, cotton lint and tobacco are commodities that can be further processed before export.

Fourth, Zimbabwe should review its debts and formulate a debt restructuring plan. These measures require major debt relief by Zimbabwe's major creditors. According to reports, Zimbabwe owed China US\$300 million in 2015. Considering that the country has no ability to repay, China directly forgave this debt. Zimbabwe will use the Chinese Yuan as a domestic currency in return, which enhances the universal status of Chinese Yuan in the international arena. Taking this as an example, Zimbabwe needs to restore contact with traditional donors including the European Union, the United States, Canada, Japan and Australia, and contact creditors in order to forgive part of its debt.

\section{Conclusion}

Generally speaking, the African economy has achieved relatively rapid growth and the agricultural development has made significant progress in recent years. Agricultural products trade between China and African countries is also in a positive development trend. There are 60 countries in Africa. The achievements of China-Africa agricultural trade have not been popularized in all countries. In addition to deepening agricultural trade cooperation with existing African countries and promoting the balanced development of bilateral agricultural trade, China also pays more attention to exploring and developing new African markets (Tang, Zhao, \& Li, 2020). China-Africa agricultural trade benefits more low-income countries in Africa. This will not only promote the development of agriculture in Africa and increase the income of local farmers but also help enrich the supply of agricultural products in China. As one of the cooperation windows, Zimbabwe's limited agricultural production capacity limits the continued development of its agricultural product trade. In the future, China and Zimbabwe's agricultural cooperation should continue to be strengthened, and Zimbabwe's agricultural assistance and agricultural investment should be used to effectively improve its agricultural products. The potential of agricultural trade between China and Zimbabwe will be further tapped because of the improvement of infrastructure in Africa, the strengthening of international cooperation, and the improvement of the business environment. The agricultural cooperation between China and Zimbabwe will become a powerful catalyst for Zimbabwe's plan to become an upper-middle-income country in 2030. China is expected to carry out agricultural cooperation with more African countries.

\section{Conflicts of Interest}

The author declares no conflicts of interest regarding the publication of this paper. 


\section{References}

Guo, F. (2020). Jointly Build the Belt and Road Initiative and Consolidate the Economic Cooperation between China and Zimbabwe. China's Foreign Trade, 5, 60-61.

Ian, P., \& Brian, R. (2000). African Nationalists and Black Workers-The 1948 General Strike in Colonial Zimbabwe. Journal of Historical Sociology, 13, 289-324.

Jiang, H. P. (2014). Zimbabwe's Agricultural Development Status and Policy Recommendations. World Agriculture, 9, 53-58.

MIC (2012). Industrial Development Policy (2012-2016). Ministry of Industry and Commerce. http://www.zimtrade.co.zw/pdf/Government\%20policies/IDP.pdf

Mothibe, T. H. (1996). Zimbabwe: African Working-Class Nationalism, 1957-1963. Zambezia, 23, 157-180.

Mukwereza, L. (2013). Chinese and Brazilian Cooperation with African Agriculture: The Case of Zimbabwe. Future Agricultures Consortium. https://www.future-agricultures.org

Tang, L. X., Zhao, W. J., \& Li, X. Y. (2020). New Developments and New Challenges of China-Africa Agricultural Cooperation under the Framework of China-Africa Cooperation Forum. West Asia and Africa, 5, 3-20.

Terence, R. (1986). Religious Movements and Politics in Sub-Saharan Africa. African Studies Review, 29, 1-69.

Wikipedia (2012). China-Zimbabwe Relations.

http://www.wikipedia.com//China-Zimbabwerelations

Yang, J., \& Chen, X. M. (2018). The Characteristics and Development Potential of Agricultural Trade between China and Africa. World Agriculture, No. 9, 23-27. 